\title{
COVID-19 pnömonisinde MinIP tekniği
}

\author{
Uğur KESIMAL(ID)
}

Recep Tayyip Erdoğan Üniversitesi Eğitim ve Araştırma Hastanesi, Radyoloji Kliniği, Rize, Türkiye

Clinic of Radiology, Recep Tayyip Erdoğan University Training and Research Hospital, Rize, Turkey

\section{ÖZ}

\section{COVID-19 pnömonisinde MinIP tekniği}

COVID-19'un nadir bildirilen bilgisayarlı tomografi bulgularından biri de hava kabarcı̆̆ işaretidir. Minimum yoğunluk projeksiyon (MinIP) görüntüleri COVID-19 pnömonisinde izlenen düşük dansite bulgularından biri olan hava kabarcığı görünümünün belirginliğini artırabilmektedir. Kırk üç ve otuz üç yaşında COVID-19 pnömonisi olan, ham toraks tomografi görüntelerinde optimal seçilemeyen, MinIP imajlarda hava kabarcığı görünümü saptanan iki olguyu sunuyoruz. Normal ince kesitli bilgisayarlı tomografi görüntülerinde hava kabarcıkları fark edilmezken, MinIP tekniği uygulandıktan sonra daha kolay fark edilebilir hale gelmektedir. Bu gözlemin radyolojik çalışmalarla doğrulanması gerekmektedir.

Anahtar kelimeler: COVID-19; bilgisayarlı tomografi; hava kabarcığı

\section{ABSTRACT}

MinIP technique in COVID-19 pneumonia

One of the rarely reported computed tomography findings of COVID-19 is an air bubble sign. Minimum intensity projection (MinIP) images can increase the prominence of the air bubble appearance, which is one of the low-density findings observed in COVID-19 pneumonia. We present two cases with COVID-19 pneumonia, who were not optimally selected on thoracic tomography images, and air bubble appearance was detected in MinIP images. While air bubbles are not noticed in normal thin-section computed tomography images, they become more easily noticeable after the MinIP technique is applied. This observation needs to be confirmed by radiological studies.

Key words: COVID-19; computed tomography; air bubble

\section{Dr. Uğur KESIMAL}

Recep Tayyip Erdoğan Üniversitesi Eğitim ve Araştırma Hastanesi, Radyoloji Kliniği,

RIZE - TÜRKIYE

e-mail: ugur_kesimal@hotmail.com

OTelif Hakkı 2021 Tüberküloz ve Toraks. Makale metnine www.tuberktoraks.org web adresinden ulassılabilir. 


\section{GiRiş}

Pandemi olarak ilan edilen Koronavirüs hastalığı 2019'un (COVID-19), kesin tanısı gerçek zamanlı polimeraz zincir reaksiyonu (RT-PCR) ile konur. Toraks bilgisayarlı tomografisinin (BT), özellikle klinik şüphenin yüksek olduğu ve ilk başvuruda negatif RT-PCR testi olan vakalarda yararlı olduğu gösterilmiştir (1). COVID-19'un nadir bildirilen BT bulguları arasında subplevral çizgiler, vasküler genişlemeler, halo veya ters halo işareti ve hava kabarcığı işareti bulunur. Minimum yoğunluk projeksiyonu (MinIP), belirli bir hacimdeki düşük yoğunluklu yapıların algılanmasını sağlayan bir veri görselleştirme yöntemidir. MinIP görüntüler COVID-19 pnömonisinde izlenen düşük dansite bulgularından biri olan hava kabarcığı görünümünün belirginliğini artırmaktadır (2). Bu olgu sunumunda ince kesitli imajlarda güçlükle seçilebilen ancak MinIP değerlendirmede daha belirgin hala gelen hava kabarcığı bulgusuna sahip olan iki olgu sunulmuştur.

\section{OLGU SUNUMU}

\section{OLGU 1}

Kırk üç yaşında kadın hasta, üç gündür olan kuru öksürük ve eklem ağrısı şikayetleri ile acil servise başvurdu. Üç yıldır tip iki diabetes mellitus için oral antidiabetik tedavi almaktaydı. Genel durumu iyi ve vitalleri stabil olan hastanın laboratuvar değerlerinde ılımlı C-reaktif protein yüksekliği dışında patoloji yoktu. Başvuru anındaki akciğer tomografisinde bilateral periferik yerleşimli multisegmenter buzlu cam dansitesinde infiltrasyonlar ve konsolidasyonlar mev- cuttu. Sağ akciğer alt lobda izlenen konsolidasyon alanı içerisinde MinIP değerlendirmede daha belirgin hale gelen hava kabarcığı görünümü izlendi (Resim 1). Hastadan kombine nazofaringeal sürüntü alınarak COVID-19 pnömoni tanısı doğrulandı. Favipiravir 2x1600 mg ilk gün, 2x600 mg dört gün ve hidroksiklorokin $2 \times 200 \mathrm{mg}$ beş gün olacak şekilde tedavi edildi.

\section{OLGU 2}

Otuz üç yaşında erkek hasta, yakınlarının COVID-19 olması nedeniyle hafif kırgınlık şikayeti ile acil servise başvurdu. Bunun dışında herhangi bir şikayeti olmayan hastanın laboratuvar değerleri normal saptandı. Yapılan toraks tomografisinde her iki akciğer periferlerinde buzlu cam dansitesinde pnömonik infiltrasyonlar izlendi. Sol akciğer alt lobdaki bir buzlu cam infiltrasyon alanı içerisinde ham görüntülerde optimal seçilemeyen MinIP imajlarda seçilebilen hava kabarcığı görünümü izlendi (Resim 2). Hastadan alınan RT-PCR testi pozitif saptandı. Hasta favipiravir tedavisi başlanarak 14 gün izolasyon önerisi ile evine gönderildi.

\section{TARTIŞMA}

COVID-19, şiddetli akut solunum sendromu koronavirüs 2'nin (SARS-CoV-2) neden olduğu bir akut solunum yolu enfeksiyon hastalığıdır (3). Aralık 2019'da, Çin'in Hubei Eyaleti, Wuhan şehrinde ortaya çıkan ve dünya çapında bir pandemiye dönüşen bu enfeksiyon hızla Çin'deki diğer şehirlere ve diğer birçok ülkeye yayıldı (4). COVID-19 pnömonisinin sık görülen toraks BT bulguları buzlu cam opasitele-

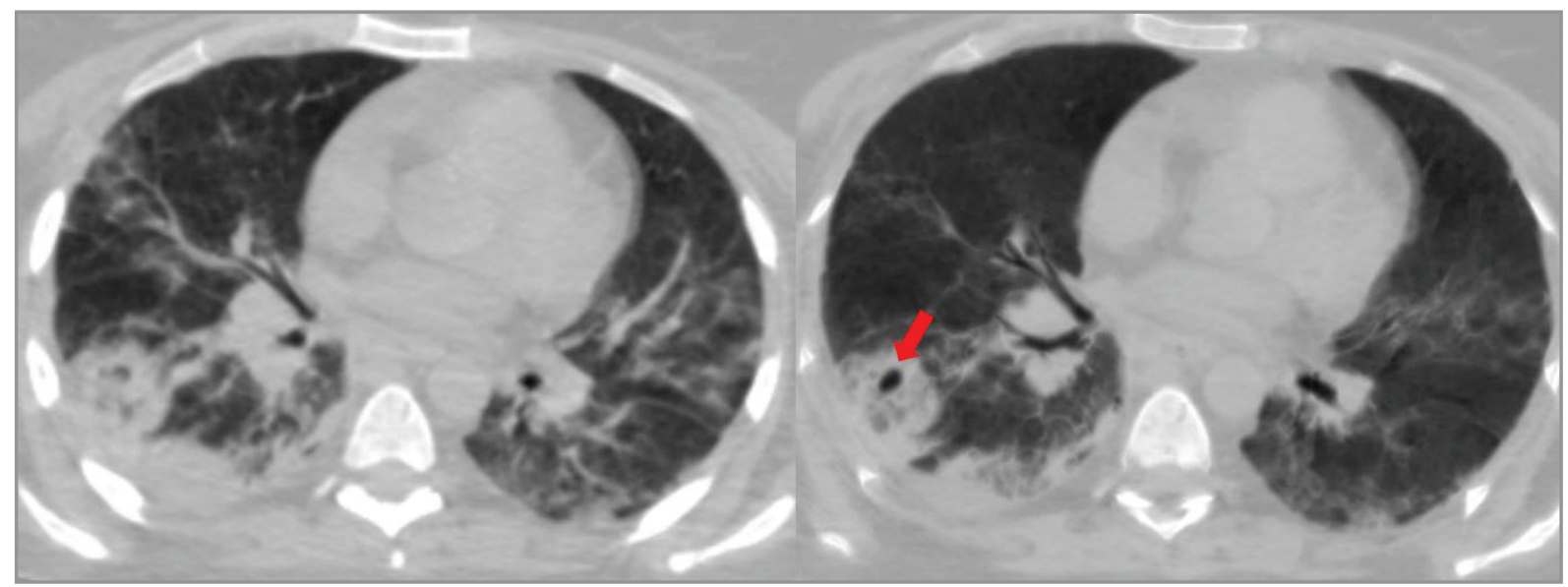

Resim 1. Kırk üç yaşında kadın hastanın torak tomografisinde sağ akciğer alt lobda konsolidasyon alanı izleniyor (soldaki resim). Sağda minimum intensite projeksiyonu uygulanan görüntüde konsolidasyon alanı içerisindeki hava kabarcı̆̆ı görünümü belirgin hale geliyor (kırmızı ok). 


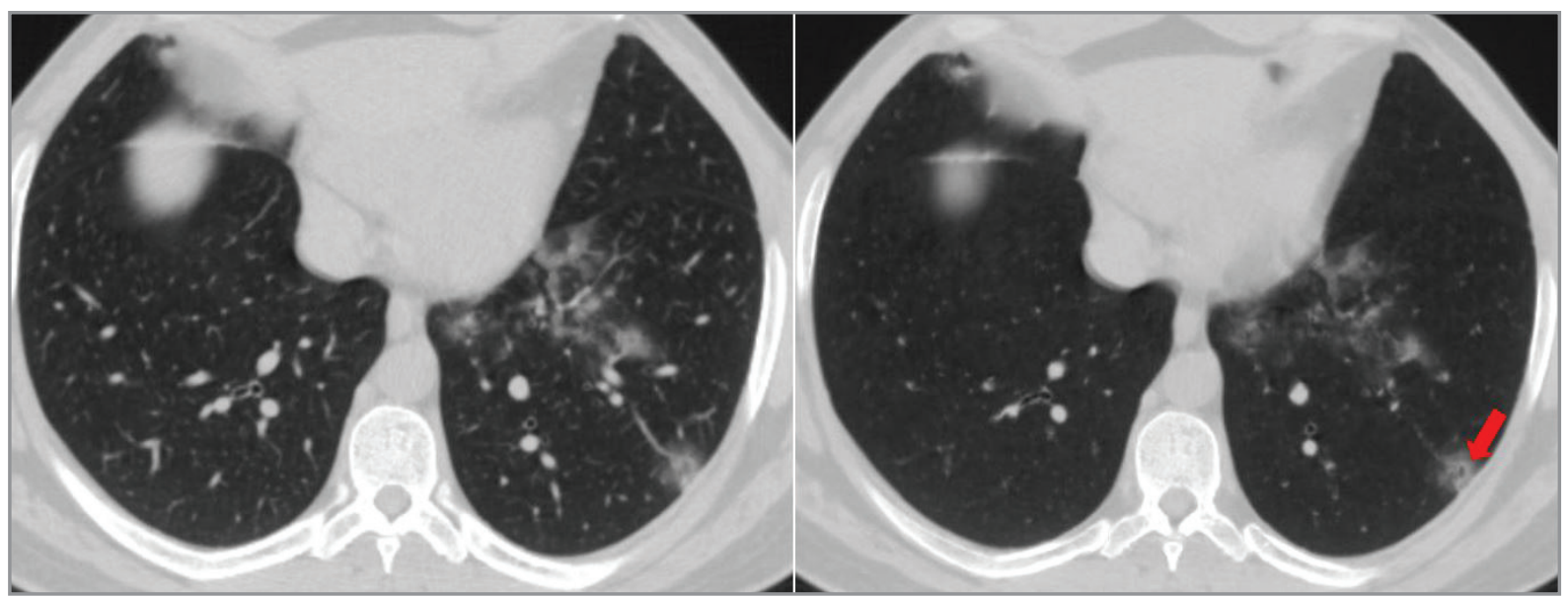

Resim 2. Otuz üç yaşında erkek hastanın sol akciğer alt lobda buzlu cam dansitesinde infiltrasyon alanı mevcuttur (soldaki resim). Sağda minimum intensite projeksiyonu uygulanmış görüntüde bu alan içerisindeki hava kabarcığı görünümü tespit ediliyor (kırmızı ok).

ri (BCO), konsolidasyonlar, intra veya interlobüler septal kalınlaşmalar ve hava bronkogramlarıdır. Daha az sıklıkla subplevral çizgiler, vasküler genişlemeler, halo veya ters halo işareti ve hava kabarcığı işareti görülür (5). BCO'ların veya konsolidasyonların olduğu alanlarda görünen küçük hava kabarcıkları, COVID-19 ile ilgili bir özellik olabileceği literatürde belirtilmektedir (2). Çünkü COVID-19 pnömonisinde görülen bu hava kabarcıkları, önceden tanımlanmış kist veya kavite tanımını (6) karşılamaz ve bu nedenle yeni bir akciğer lezyonları sınıfını temsil eder. Bu küçük hava yoğunluğu yapıları, muhtemelen bronşiyollerin genişlemesine veya konsolidasyonların emilimine sekonder olduğu düşünülmektedir $(1,4)$. Rutin toraks BT incelemelerinde 1 mm'lik bir kesit kalınlığı tercih edilmektedir çünkü daha kalın dilimler kullanılarak yapılan değerlendirmelerde küçük lezyonlar kolayca gözden kaçabilir. Bununla birlikte bizim olgularımızda da gösterdiğimiz gibi ince kesitli BT verilerini kullanarak 4-5 mm MinIP görüntüleri oluşturmak küçük hava kabarcıklarının belirginliğini artırır. Böylelikle normal ince kesitli BT görüntülerinde hava kabarcıkları fark edilmezken, MinIP tekniği uygulandıktan sonra daha kolay fark edilebilir hale gelir. MinIP tekniği, tanım gereği, belirli bir hacimdeki düşük yoğunluklu yapıların tespitini sağlar. Algoritma hacim boyunca her görüntüdeki en düşük atenüasyon değerine sahip verileri kullanarak, vokselin iki boyutlu bir görüntü projeksiyonunu sağlar. Bu nedenle Minlp tekniği buzlu cam opasitesi, mozaik patern, traksiyon bronşektazisi, kistik akciğer hastalığı (7) gibi durumlarda lokalizasyon tespiti ve ölçüm için kullanabilmektedir. Özellikle son yıllarda rutin BT değerlendirmesi sırasında elde edilen aksiyel kesitlerin üç veya dördünün birleştirilip yeniden biçimlendirildiği ve yüksek yoğunluklu oluşumların vurgulandığı kalın kesitlerin kullanıldığı bir BT görüntüleme yazılımı olan maksimum yoğunluk projeksiyonu (MIP) yöntemi giderek yaygınlaşmaya başlamıştır. Orijinal aksiyel görüntülerden farklı olarak, bu yöntem nodül ve çevresindeki parankim arasındaki kontrastı artırır ve pulmoner nodüllerin saptanmasında nodülün fark edilebilirliğine katkıda bulunur (8). MinIP'de bu yöntemle aynı mantığı kullanarak düşük dansite bulgularının belirginliğini artırır. Sunduğumuz bu olgularda da olduğu gibi BCO'lar içindeki küçük hava içeren yapılar MinIP değerlendirmede daha belirgin hale gelmektedir. Bu gözlemimizin geniş serili tanısal doğruluk çalışmalarıyla doğrulanması gerekmektedir.

\section{ÇIKAR ÇATIŞMASI}

Yazarlar bu makale ile ilgili herhangi bir çıkar çatışması bildirmemişlerdir.

\section{YAZAR KATKISI}

Anafikir/Planlama: UK

Analiz/Yorum: UK

Veri sağlama: UK

Yazım: UK

Gözden Geçirme ve Düzeltme: UK

Onaylama: UK 


\section{KAYNAKLAR}

1. Shi H, Han X, Jiang N, Cao Y, Alwalid O, Gu J, et al. Radiological findings from 81 patients with COVID-19 pneumonia in Wuhan, China: a descriptive study. Lancet Infect Dis 2020; 20(4): 425-34.

2. Savaş R. MinIP technique may be helpful in diagnosing COVID-19. Diagn Interv Radiol 2020; 26: 604-5.

3. Fu B, Hu L, Lv F, Huang J, Li W, Ouyang Y, et al. Follow-up $C T$ results of COVID-19 patients with initial negative chest CT. Infect Drug Resist 2020; 13: 2681-87.

4. Kanne JP. Chest CT findings in 2019 Novel Coronavirus (2019-nCoV) infections from Wuhan, China: key points for the radiologist. Radiol 2020; 295(1): 16-7.

5. Ye $Z$, Zhang $Y$, Wang $Y$, Huang $Z$, Song B. Chest CT manifestations of new coronavirus disease 2019 (COVID-19): a pictorial review. Eur Radiol 2020; 30(8): 4381-9.

6. Hansell DM, Bankier AA, MacMahon H, McLoud TC, Müller NL, Remy J. Fleischner Society: glossary of terms for thoracic imaging. Radiol 2008; 246(3): 697-722.

7. Perandini S, Faccioli N, Zaccarella A, Re T, Mucelli RP. The diagnostic contribution of CT volumetric rendering techniques in routine practice. Indian / Radiol Imaging 2010; 20(2): 92-7.

8. Ghonge NP, Chowdhury V. Minimum-intensity projection images in high-resolution computed tomography lung: technology update. Lung India 2018; 35(5): 439-40. 